How to cite this article:

Mohammad Al Dweiri, M. A., \& Mat Isa, R. (2019). Supply chain integration and supply chain performance: The role of knowledge sharing as a mediator. International Journal of Management Studies, 26(2), 21-51.

\title{
SUPPLY CHAIN INTEGRATION AND SUPPLY CHAIN PERFORMANCE: THE ROLE OF KNOWLEDGE SHARING AS A MEDIATOR
}

\author{
MOHAMMAD AHMED MOHAMMAD AL DWEIRI \\ Zaytoonah University of Jordan, Jordan \\ *ROSMAH MAT ISA \\ Faculty of Economics and Management \\ Universiti Kebangsaan Malaysia \\ *Corresponding author: rosmah@ukm.edu.my
}

\begin{abstract}
The purpose of this paper is to examine the mediating role of knowledge sharing in the relationship between supply chain integration and supply chain performance. This study used a survey questionnaire for a sample size of 277 managers from various sectors in the manufacturing industry in Jordan. This study utilised PLS Structural Equation Modeling for testing the hypothesis. The finding indicates a significant positive relationship between supply chain integration and supply chain performance and that knowledge sharing plays partial mediation in this relationship. This study provides an important implication on the role of knowledge sharing. The performance of the supply chain can be maximised if the supply chain partners share knowledge among them. This will expedite the process of delivering the products to the customers. Awareness among partners on the importance to share and utilise knowledge better should be raised. The study contributes to the research on supply chain management by advancing the understanding of the role of knowledge sharing that can increase the performance of the supply chain partners.
\end{abstract}


Keywords: Supply chain integration, supply chain management, knowledge sharing, supply chain performance, supplier integration.

Received: 3/1/2020 Revised: 19/4/2020 Accepted: 6/5/2020 Published: 25/6/2020

\section{Introduction}

Researchers and practitioners have noted that globalisation and knowledge-intensive economy has shifted modern business competition from between organisations to between supply chains (Näslund \& Hulthen, 2012; Huang, Yen \& Liu, 2014). Thus, supply chain management has become an important management field as it becomes a catalyst for organisations to stay competitive in the global markets. However, to enhance supply chain performance requires the organization to participate and focus on the activities that it does best in the supply chains (Hugos, 2018), for example, by establishing collaborative and mutually beneficial partnerships with its supply chain partners, which ultimately may obtain a competitive advantage (Stock, Boyer \& Harmon, 2010). As such, superior supply chain performance demands effective and efficient supply chain collaboration and coordination, or in other words, an integration among all supply chain partners (He, Keung, Sun \& Chen, 2014).

The goal of integration is to accomplish both real-time transmission and to process information that is essential for supply chain decisionmaking. Hence, the integration depends on the knowledge shared by the supply chain partners (Marra, Ho \& Edwards, 2012). Existing studies showed that efficient knowledge sharing among supply chain partners plays a significant role in improving integration among supply chain partners (Goury, Samuel, Gunasekaran \& Spalanzani, 2011; Cheng, 2011), reducing costs of inventories and shortages (Lee, So \& Tang, 2000), enhancing supply chain performance (Marra et al., 2012; Yurong \& Mingwei, 2010), and establishing interfirm collaborative innovations with higher levels of performance (Wang \& $\mathrm{Hu}, 2017)$. In addition, it is also evident in the previous studies that supply chain integration and knowledge sharing are the two significant sources that improve supply chain performance(e.g., Cheng \& Fu, 2013; Goury et al., 2011; Kembro \& Näslund, 2014; Khalfan, Kasyap; Li \& Abbott, 2010). Hence, it is imperative to understand 
the function of knowledge sharing in this relationship to enable the supply chain partners to know how to exploit it for better decisionmaking, gain competitive advantage, and survive in the global market. Nevertheless, the role of knowledge sharing as a mediator in the relationship between supply chain integration and supply chain performance is yet to be understood. Underpinned by Transaction Cost Theory and Knowledge-Based View, this study aims to examine the mediating role of knowledge sharing in the relationship between supply chain integration and supply chain performance.

\section{Literature Review}

\section{Supply Chain Integration and Supply Chain Performance}

It is generally acknowledged that supply chain integration is critical in creating value for the supply chain partners (Huang et al., 2014; Huo, 2012; Vallet-Bellmunt \& Rivera-Torres, 2013). Past literature emphasised the critical role of supply chain integration in achieving performance and gaining competitive advantages (e.g., Flynn, Huo \& Zhao, 2010; Huang et al., 2014). Moreover, studies on supply chain integration proposed different approaches and dimensions to conceptualise the concept (Schoenherr \& Swink, 2012). While some studies operationalised supply chain integration as uni-dimension (e.g., Boon-Itt, 2011; Fynes, Voss \& De Búrca, 2005; Kim, 2009;), others utilised the multi-dimension operationalisation and differentiated between external and internal integration (Flynn et al, 2010; Droge, Vickery \& Jacobs, 2012; Vallet-Bellmunt \& Rivera-Torres, 2013). Following the recent research (e.g., He et al., 2014; Williams, Roh, Tokar \& Swink, 2013; Zhang, Gunasekaran \& Wang, 2015), this study conceptualised supply chain integration as a multi-dimension concept, which includes three dimensions namely, internal, customer, and supplier integrations.

Internal integration has been conceptualised as the extent to which internal functional department (e.g., sales, marketing, purchasing, finance, operations, logistics, engineering, and information technology) operates together to achieve supply chain objectives and goals. Previous studies indicate that internal integration has a positive impact on not only the supply chain agility (Braunscheidel \& Suresh, 2009), but also the quality, cost, delivery, and flexibility (Wong, 
Boon-Itt \& Wong, 2011a), which in turn improved the operation and business performance (Flynn et al., 2010). On the other hand, external integration refers to the integration or collaboration with outside parties, specifically the customers and suppliers (Flynn et al., 2010; Frohlich \& Westbrook, 2001). The purpose of customer integration is to maximise customer value through coordinating the flow of material, money, and information (Flynn et al., 2010; Schoenherr \& Swink 2012; Zhao, Huo, Selen \& Yeung, 2011). Meanwhile, the role of supplier integration is to manage the business processes strategically by integrating the information and planning and jointly producing development between the focal organisation and its suppliers (Wong et al., 2011a).

It is widely recognised in the literature that the better the supply chain integration, the higher the levels of performance (Cagliano et al., 2006; Danese \& Romano, 2011; Huo, 2012). For instance, Cousins and Menguc (2006) found a positive relationship between supplier integration and supplier communication's performance, while Petersen, Handfield and Ragatz (2005) found a positive relationship between supplier integration and product development performance. Transaction Cost Theory postulates that an organisation should aim to reduce the costs of managing exchanges inside the organisation and the costs of exchanging resources in the environment (Williamson, 1985). Hence, organisations that integrate internally and externally with their supply chain partners may improve their strategic performance, such as, introducing new product quickly for faster reaction to changes in the business environment and gaining competitive advantage. It may also improve the supply chain operational performance, such as, fostering order fulfillment cycle time, minimising supply chain operations cost and increasing business volume.

$\mathrm{H}_{1}$ : Supply chain integration has a positive relationship with supply chain performance

\section{Supply Chain Integration and Knowledge Sharing}

Knowledge sharing is defined in this study as the internal flow of knowledge within the firm and external flow of knowledge with the supply chain partners (Ingram \& Baum, 1997). Knowledge sharing in the context of supply chain management is dichotomised into two components: internal knowledge sharing (i.e., between functional 
departments), and external knowledge sharing (i.e., knowledge sharing with supplier, knowledge sharing with the customer). Previous studies explained the role of supply chain integration as a facilitator of knowledge sharing among the supply chain partners (e.g., Barratt \& Barratt, 2011; Kanda \& Deshmukh, 2008). Hence, the more integration within the organisation and between the supply chain partners, the more benefits the organisations are expected to gain as it enhances the willingness to share knowledge and information (Croom et al., 2007). For instance, one of the benefits of supply chain integration is it enables the promotion of organisational relationships, which, in turn, foster the effort of information and knowledge sharing among supply chain partners (Konukcu, 2011; Montoya-Torres \& Ortiz-Vargas, 2014). The Transaction Cost Theory posits that supply chain integration helps supply chain partners to gain benefits through mutual exchange of knowledge and information to minimise searching for information cost (Willamson, 1985; Winter, 1988). Therefore, integration is considered an essential key to enhancing knowledge and information sharing (Olorunniwo \& Li, 2010).

$\mathrm{H}_{2}$ : Supply chain integration has a positive relationship with knowledge sharing

\section{Knowledge Sharing and Supply Chain Performance}

In the era of the knowledge-based economy, knowledge has become a significant resource for organisations to stay competitive (Yifei \& Taofei 2010: Yurong \& Mingwei 2010). Knowledge has become a critical issue in supply chain management because knowledge represents one of the three flows (raw materials, money, and knowledge) needed to improve the supply chain performance (Li, Sikora, Shaw \& Tan, 2006; Zhou \& Benton, 2007). Thus, effective knowledge sharing among supply chains partners has become a significant way of improving the overall supply chain performance to gain a competitive advantage (Huang \& Lin, 2010; Yurong \& Mingwei, 2010). This is because effective knowledge sharing may enhance market competitiveness within the whole supply chain (Yifei \& Taofei, 2010), support decisionmaking within the supply chain (Wu \& Zang, 2009), reduce supply chain costs (Dyer \& Nobeoka, 2002), increase material flow (Kaipia, 2009), enable faster delivery (Lyons, Coleman, Kehoe \& Coronado, 2004) and improve order fulfillment rate (Govindarajan \& Gupta, 2001). 
Additionally, previous studies have proved that there is a positive relationship between different forms of knowledge sharing, internal knowledge sharing and supply chain performance (e.g., Leiponen, 2006; Barratt \& Barratt, 2011; Wong, Lai \& Cheng, 2011b), and external knowledge sharing and supply chain performance (Barratt \& Barratt, 2011; Li \& Hu, 2012; Lotfi, Mukhtar, Sharan \& Zadeh, 2013; Wong et al,. 2011b; Yurong \& Mingwei, 2010). Knowledge-Based View regards knowledge as a unique, important and strategic resource of a firm; when deployed strategically, it can yield differential performance implications (Grant, 1996b). It is argued that knowledge is "the set of justified beliefs that improve an entity's capacity for effective action" (Alavi \& Leidner, 2001, 109). Thus, sharing knowledge within and outside of the organisation with the supply chain partners might enhance the supply chain performance.

$\mathrm{H}_{3}$ : Knowledge sharing has a positive relationship with supply chain performance

\section{Supply Chain Integration, Knowledge Sharing, and Supply Chain Performance}

Previous studies have explained that knowledge sharing is a product of supply chain integration between the supply chain partners (e.g., Barratt \& Barratt, 2011; Gunasekaran et al., 2017; Kanda \& Deshmukh, 2008) and becomes a fundamental driver of effective and efficient supply chain performance ( $\mathrm{Li} \& \mathrm{Lin}, 2006$ ). This notion is also supported by Kembro and Näslund (2014) and Kembro et al. (2014) in which they highlighted the significant role of knowledge sharing in enhancing the supply chain performance. However, there is no study on the mediation effect of knowledge sharing between supply chain integration and supply chain performance. To overcome this problem and to fill the gap in the literature of supply chain management, this study used Transaction Cost Theory and Knowledge-Based View to hypothesize the relationship between supply chain integration, knowledge sharing, and supply chain performance. Transaction Cost Theory posits that knowledge sharing is a product of supply chain integration, which helps supply chain partners to gain benefits through mutual exchange of knowledge and information in order to minimise searching for information cost (Willamson 1985; Winter 
1988). Knowledge-Based View postulates that the more knowledge is shared within the organisation and among supply chain partners, the more benefits the organizations are expected to gain such as enhancing the supply chain performance (Grant, 2011; Sáenz, Aramburu \& Blanco, 2012).

$\mathrm{H}_{4}$ : Knowledge sharing mediates the relationship between supply chain integration and supply chain performance

\section{Methodology}

\section{Data}

The population of the present study is the manufacturing organisation in Jordan, in ten different industrial sectors, such as mining, construction, chemical and cosmetics, and plastic and rubber. There is no standard database available in details about the manufacturing organization in Jordan. Therefore, to identify the sample, the required information is obtained from the website of the Ministry of Industry and Trade and Supply. Also, some of the information was obtained from the websites of the organizations, such as Jordan Phosphate Mines Company, Arab Potash, and Lafarge Jordan. Based on the Cohen (1992) sample determination table, taking into account type I and type II errors, the sample size was determined based on a significance level of 0.01 (reliability level=95\%), a desired power of 0.80 , and a medium effect size. The required minimum sample should be at least 158 with two independent variables.

Convenience sampling was utilised to collect data from the supply chain executive, senior supply chain managers in procurement, operations and logistic functions working in these organizations. The respondents were chosen based on their responsibilities towards supply chain integration (Saraf, Langdon \& Gosain, 2007; Schoenherr \& Swink, 2012) and their significant roles towards knowledge management (Choi \& Lee, 2003; Nonaka \& Takeuchi, 1995).

Prior to data collection, the lead researcher visited the human resource department or the front service desk of the companies to get approvals 
for distributing the questionnaires. The approvals were obtained using two approaches. In the first approach, some of the companies allowed the researcher to approach the managers' offices directly to distribute the questionnaires personally. The researcher requested the managers to answer the questionnaires within two weeks and return them to secretary offices. For the second approach, some companies' assigned officers from the human resource department to distribute the questionnaires to the managers. The researcher provided the human resource officers with the questionnaires and met them again to collect the completed questionnaires on the agreed dates. In total, 350 questionnaires were distributed, however, only 280 questionnaires were returned with a response rate of 80 percent. Three invalid questionnaires were removed and the remaining 277 questionnaires were used for analysis.

\section{Measures}

The study considers supply chain integration as a multi-dimensional latent construct, which underlies its three dimensions, namely internal integration, supplier integration, and customer integration. Internal integration refers to the extent to which internal functional department work together to accomplish the supply chain planning and execution. Meanwhile, customer integration refers to the extent to which specific customers and their needs are incorporated into planning and execution activities. Supplier integration is defined as the extent to which planning and execution were incorporated and synchronised with the suppliers' capabilities. All items were adapted from Schoenherr and Swink (2012).

Knowledge sharing is operationalised as a multi-dimensional latent construct that includes the internal flow of knowledge within the firm and the external flow of knowledge with suppliers and customers. Internal knowledge sharing refers to transferring or sharing of the existing knowledge among employees within and between departments as well as hierarchical levels (Martín-De Castro, Andreeva \& Kianto, 2011). Examples of the items include, "In our organization, employees and managers share a lot of information and knowledge" and "Our employees are systematically informed of changes in procedures, instructions, and regulations." While for supplier and 
customer knowledge sharing is described as knowledge sharing about the joint action with key suppliers and key customers, such as in production process and manufacturing technology. Some of the items are "Our company share knowledge about ongoing design and engineering changes with suppliers", "Our company share knowledge about the selection of customers with suppliers", and "Our company share knowledge with customers about modifications needed to the production schedules to suit their requirements." Internal knowledge sharing was measured using a five-item scale adapted from Martín-De Castro et al. (2011), while supplier and customer knowledge sharing was measured using a seven-item scale for each of the dimension adapted from Reychav (2009).

Supply chain performance is operationalised as the opportunities inherent in the long-term inter-organizational relationships and the improvements in the supply chain processes. It includes operational and strategic supply chain performance. Operational performance is related to the improvements of specific supply chain processes, such as efficient inventory management and shorter delivery cycles. Strategic performance is associated with the increasing business volume between supply chain partners, the strengthening of partnerships, and the ability of the partners to work together in response to the needs of customers. All items were adapted from Niu (2010) using a 5-point Likert scale. The questionnaire was translated back to back from English to the Arabic language as most of the respondents do not understand English.

The present study solved the issue of Common Method Variance (CMV) through firstly, using multiple-items for supply chain integration, knowledge sharing and supply chain performance (Craighead, Ketchen, Cunn \& Hult, 2011). Secondly, validity is also assured through the face and content validity in which items related to the construct used simple, clear and understandable language. Thirdly, the current study used Harman's single-factor (Lee \& Podsakoff, 2003; Podsakoff, Mackenzie) to test the method's bias. The results of Harman's single factor test show that the total variance explained by each item varied from 25.845 to 0.035 . Podsakoff et al. (2003) argued that if the variance is explained by a single factor for all data, it indicates the presence of method bias. In the current study, 
the variance is explained by all factors. Thus, the problem of CMV did not exist.

\section{Analysis Procedures}

In this research, SPSS and Smart-PLS (version 3) were utilised to analyse data. PLS-SEM is appropriate for analysing data with multi-dimensions' constructs (reflective-formative). For instance, the investigation of the dimensions under supply chain integration requires a two-stage approach. The two-stage approach consists of the first order and second order (Chin, Marcolin, \& Newsted, 2003; Henseler \& Chin, 2010).

\section{Analysis}

\section{Demographic of Companies}

Table 1 shows that 73 percent of organisations with 250 to 500 employees participated in this study and another 12 percent have more than 500 employees. This indicates that approximately 80 percent of organisations that participated in this study are in the range of medium to high size organisations. Furthermore, 56 percent of organisations are operating in the regional markets, while 30 percent of organizations are in the local and national markets, which indicate that the majority of organisations are focusing on the local markets.

Table 1

Demographic of Companies

\begin{tabular}{llcc}
\hline \multicolumn{2}{l}{ Demographics Variables } & $\begin{array}{c}\text { Number of } \\
\text { companies }\end{array}$ & Percentage (\%) \\
\hline Number of & Less than 50 & 4 & $1.5 \%$ \\
employees & $50-100$ & 10 & $3.5 \%$ \\
& $1100-250$ & 27 & $10 \%$ \\
& $250-500$ & 202 & $73 \%$ \\
& More than 500 & 34 & $12 \%$ \\
\hline
\end{tabular}


IJMS 26(2), 21-51 (2019)

\begin{tabular}{llcc}
\hline Demographics Variables & $\begin{array}{c}\text { Number of } \\
\text { companies }\end{array}$ & Percentage (\%) \\
\hline Firm's market & Local / National & 155 & $56 \%$ \\
& Regional & 83 & $30 \%$ \\
& Global / International & 39 & $14 \%$ \\
Operational & Less than 1 year & 6 & $2 \%$ \\
years of the & $1-5$ years & 16 & $6 \%$ \\
& $5-10$ years & 27 & $10 \%$ \\
& $10-15$ years & 142 & $51 \%$ \\
& $15-20$ years & 69 & $25 \%$ \\
& More than 20 years & 17 & $6 \%$ \\
\hline
\end{tabular}

\section{Measurement Model}

\section{First-order constructs}

The first order constructs were assessed based on two criteria, reliability and validity. The factor loadings and composite reliabilities of all items were above 0.70 recommended thresholds. The convergent validity was also supported as the average variances extracted were all above 0.50 , the acceptability level (Table 2 ).

Table 2

Factor Loading

\begin{tabular}{lllcll}
\hline Constructs & Dimensions & Items & Loading & CR & AVE \\
\hline & & InIng2 & 0.770 & 0.830 & 0.551 \\
& Internal & InIng3 & 0.714 & & \\
integration & InIng4 & 0.755 & & \\
Supply chain & & InIng5 & 0.730 & & \\
Integration & & CI2 & 0.670 & 0.828 & \multirow{2}{*}{0.548} \\
& Customer & CI3 & 0.830 & & \\
& integration & CI4 & 0.710 & & \\
& & CI5 & 0.753 & & \\
\hline
\end{tabular}

(continued) 
IJMS 26(2), 21-51 (2019)

\begin{tabular}{|c|c|c|c|c|c|}
\hline Constructs & Dimensions & Items & Loading & $\mathrm{CR}$ & AVE \\
\hline \multirow{19}{*}{$\begin{array}{l}\text { Knowledge } \\
\text { Sharing }\end{array}$} & \multirow{4}{*}{$\begin{array}{l}\text { Supplier } \\
\text { integration }\end{array}$} & SI1 & 0.728 & 0.850 & 0.585 \\
\hline & & SI3 & 0.780 & & \\
\hline & & SI4 & 0.732 & & \\
\hline & & SI5 & 0.815 & & \\
\hline & \multirow{5}{*}{$\begin{array}{l}\text { Internal } \\
\text { knowledge } \\
\text { sharing }\end{array}$} & IKS1 & 0.760 & 0.834 & 0.504 \\
\hline & & IKS2 & 0.730 & & \\
\hline & & IKS3 & 0.780 & & \\
\hline & & IKS4 & 0.660 & & \\
\hline & & IKS5 & 0.604 & & \\
\hline & \multirow{6}{*}{$\begin{array}{l}\text { Knowledge } \\
\text { sharing with } \\
\text { customer }\end{array}$} & $\mathrm{KSC} 1$ & 0.740 & 0.902 & 0.605 \\
\hline & & $\mathrm{KSC} 2$ & 0.801 & & \\
\hline & & $\mathrm{KSC} 4$ & 0.820 & & \\
\hline & & KSC5 & 0.783 & & \\
\hline & & KSC6 & 0.820 & & \\
\hline & & KSC7 & 0.702 & & \\
\hline & \multirow{4}{*}{$\begin{array}{l}\text { Knowledge } \\
\text { sharing with } \\
\text { supplier }\end{array}$} & KSS4 & 0.640 & 0.832 & 0.556 \\
\hline & & KSS5 & 0.840 & & \\
\hline & & KSS6 & 0.793 & & \\
\hline & & KSS7 & 0.701 & & \\
\hline \multirow{6}{*}{$\begin{array}{l}\text { Supply chain } \\
\text { Performance }\end{array}$} & \multirow{3}{*}{$\begin{array}{l}\text { Operational } \\
\text { performance }\end{array}$} & OP2 & 0.701 & 0.665 & 0.582 \\
\hline & & OP3 & 0.740 & & \\
\hline & & OP4 & 0.842 & & \\
\hline & \multirow{3}{*}{$\begin{array}{l}\text { Strategic } \\
\text { performance }\end{array}$} & SP3 & 0.822 & 0.852 & 0.658 \\
\hline & & SP4 & 0.806 & & \\
\hline & & SP6 & 0.805 & & \\
\hline
\end{tabular}

$\mathrm{CI}=$ Customer Integration, InIng= Internal Integration, $\mathrm{SI}=$ Supplier Integration, KSC = Knowledge Sharing with Customer, KSS = Knowledge Sharing with Supplier, IKS= Internal Knowledge Sharing, OP = Organisational Performance, $\mathrm{SP}=$ Strategic Performance

Fornell-Larcker analysis confirms that all of the diagonal correlation values are greater than other corresponding correlation values below them; an indication of the discriminant legitimacy of all reflective constructs of the first order model (Table 3). 
IJMS 26(2), 21-51 (2019)

Table 3

Fornell-Larcker Measurement

\begin{tabular}{lllllllll}
\hline & CI & IKS & InIng & KSC & KSS & OP & SI & SP \\
\hline CI & $\mathbf{0 . 7 4}$ & & & & & & & \\
IKS & 0.28 & $\mathbf{0 . 7 1}$ & & & & & & \\
InIng & 0.22 & 0.38 & $\mathbf{0 . 7 4}$ & & & & & \\
KSC & 0.51 & 0.12 & -0.01 & $\mathbf{0 . 7 8}$ & & & & \\
KSS & 0.39 & 0.18 & 0.15 & 0.60 & $\mathbf{0 . 7 5}$ & & & \\
OP & 0.10 & -0.05 & 0.00 & 0.17 & 0.11 & $\mathbf{0 . 7 6}$ & & \\
SI & 0.27 & 0.15 & 0.22 & 0.12 & 0.13 & 0.05 & $\mathbf{0 . 7 3}$ & \\
SP & 0.29 & 0.28 & 0.30 & 0.33 & 0.31 & 0.09 & 0.26 & $\mathbf{0 . 8 1}$ \\
\hline
\end{tabular}

$\mathrm{CI}=$ Customer Integration, InIng= Internal Integration, $\mathrm{SI}=$ Supplier Integration, $\mathrm{KSC}=$ Knowledge Sharing with Customer, KSS $=$ Knowledge Sharing with Supplier, IKS= Internal Knowledge Sharing, OP = Organisational Performance, $\mathrm{SP}=$ Strategic Performance

\section{Second-order constructs}

From the first stage (first-order), the new latent values for formative constructs: knowledge sharing, supply chain integration, and supply chain performance need to be measured for the second-order constructs. This was done through normality, convergent validity, multicollinearity and outer weight to assess the significance and relevance of the formative constructs (Hair, Hult, Ringle \& Sarstedt, 2017). Kolgomorov-Sminov and Shapiro-Wilk's frameworks were used to check for normality (Table 4). 
IJMS 26(2), 21-51 (2019)

Table 4

Normality Test for Formative Constructs

\begin{tabular}{ccccccc}
\hline & \multicolumn{2}{c}{ Kolmogorov-Smirnov } & \multicolumn{3}{c}{ Shapiro-Wilk } \\
& Statistic & $\mathrm{df}$ & Sig. & Statistic & $\mathrm{df}$ & Sig. \\
\hline KS & 0.098 & 277 & 0.000 & 0.947 & 277 & 0.000 \\
SCI & 0.060 & 277 & 0.017 & 0.955 & 277 & 0.000 \\
SCP & 0.061 & 277 & 0.015 & 0.974 & 277 & 0.000 \\
\hline
\end{tabular}

$\mathrm{SCI}=$ Supplier Chain Integration, $\mathrm{KS}=$ Knowledge Sharing, $\mathrm{SCP}=$ Strategic Chain Performance

In this case, all the variables have a significant value of less than 0.05 , which confirmed that the data were not normally distributed. Hence, PLS-SEM was used for further analysis as it could handle extremely non-normal data and has no assumptions about the data distributions (Hair et al., 2017; Hair, Sarstedt, Lucas \& Volker, 2014). Convergent Validity was examined using Wells et al.'s (2011) approach, which calculates the redundancy for every formative construct separately by creating a formative and reflective model in PLS. The formative construct was measured using the latent variable scores from the first-order constructs as formative indicators. Redundancy analysis correlates the formative construct with reflective dimensions to examine the strength of the relationship between them (Lowry \& Gaskin, 2014; Wong, 2013). The rule of thumb is R2 value of 0.80 and above indicates a strong convergent validity, while $\mathrm{R} 2$ value of less than 0.64 shows lack of convergent validity (Hair et al., 2017). The results for the R2 value in the formative model of supply chain integration, knowledge sharing and supply chain performance are above 0.80 , which indicate a strong convergent validity for all formative constructs. Table 5 shows all the constructs have VIF value between 1 and 10, indicating no presence of multicollinearity within these constructs. 
IJMS 26(2), 21-51 (2019)

Table 5

Multicollinearity

\begin{tabular}{llll}
\hline & KS & SCI & SCP \\
\hline KS & - & - & 1.60 \\
SCI & 1.001 & - & 1.49 \\
SCP & - & - & \\
\hline
\end{tabular}

$\mathrm{SCI}=$ Supplier Chain Integration, $\mathrm{KS}=$ Knowledge Sharing, $\mathrm{SCP}=$ Strategic Chain Performance

To assess the significance and relevance of the formative constructs, the outer weights were calculated. The outer weights for the secondorder constructs measured the quality of the formative measurement model. The outer-weights were assessed through the results obtained from the total effect of the bootstrapping procedure (5000 resample) in PLS (Ringle, Wende \& Becker, 2015). Then, $t$ values were calculated to assess each formative construct weights significance. Table 6 shows the $t$-statistics values for supply chain integration dimensions, knowledge sharing dimensions, and supply chain performance dimensions are greater than 2.54 and significant at one percent $(p<0.01)$.

Table 6

\section{T-Statistics}

\begin{tabular}{llllll}
\hline \multirow{2}{*}{ Dimension /Construct } & $\begin{array}{l}\text { Original } \\
\text { Sample }\end{array}$ & $\begin{array}{l}\text { Sample } \\
\text { Mean }\end{array}$ & $\begin{array}{l}\text { Standard } \\
\text { Deviation }\end{array}$ & T Statistics & P Values \\
\hline InIng -> SCI & 0.3888 & 0.3859 & 0.0338 & 11.5063 & 0.000 \\
CI -> SCI & 0.5964 & 0.5941 & 0.0258 & 23.0973 & 0.000 \\
SI -> SCI & 0.4227 & 0.4219 & 0.0318 & 13.3023 & 0.000 \\
IKS-> KS & 0.1910 & 0.01901 & 0.0157 & 12.1845 & 0.000 \\
KSC -> KS & 0.6913 & 0.6904 & 0.0156 & 44.3070 & 0.000 \\
KSS -> KS & 0.3603 & 0.3596 & 0.0150 & 34.3328 & 0.000 \\
OP-> SCP & 0.4294 & 0.4291 & 0.0221 & 19.4430 & 0.000 \\
SP -> SCP & 0.8635 & 0.8617 & 0.0226 & 38.1382 & 0.000 \\
\hline
\end{tabular}

$\mathrm{CI}=$ Customer Integration, InIng= Internal Integration, SI= Supplier Integration, KSC = Knowledge Sharing with Customer, KSS = Knowledge 
Sharing with Supplier, IKS= Internal Knowledge Sharing, OP = Organisational Performance, $\mathrm{SP}=$ Strategic Performance

\section{Structural Model}

The latent values index of the first-order model was entered into the second-order model of the PLS-SEM modelling. After establishing a valid and reliable measurement model, the next step is to assess the structural model using PLS path analysis. Figure 1 shows the structural model and the estimated path coefficients $(\beta)$, R-square value, and $t$-values (critical ratio) after running the bootstrapping with 5000 re-sampling.

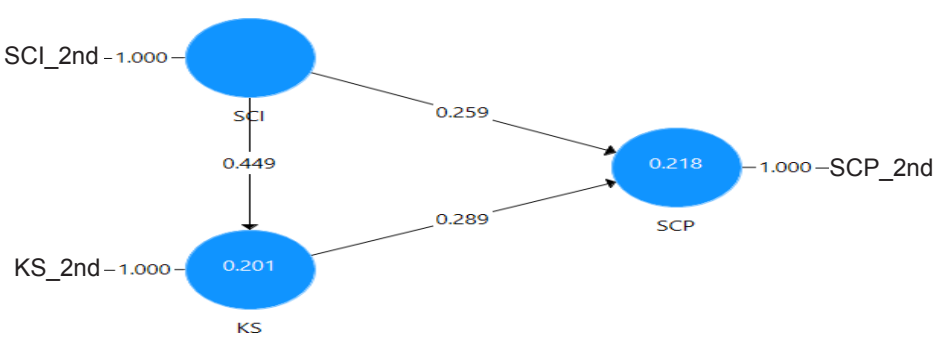

Figure 1. The effect of knowledge sharing and supply chain integration on supply chain performance.

According to the model analysis, the model can explain 0.218 or 21.8 percent variance of supply chain performance. This indicates that supply chain integration and knowledge sharing can explain the supply chain performance with moderate strength (Cohen, 1988). In this case, both KS and SCI are positively influencing the SCP. This explains that with the increase in knowledge sharing and supply chain integration, the supply chain performance would go high; and if knowledge sharing and supply chain integration go down, the supply chain performance will be reduced. Moreover, according to the model analysis, the R-square value for KS is 0.201 , indicating the supply chain integration can explain 20.1 percent variance of knowledge sharing. This explains that with the increase in supply chain integration, knowledge sharing would go high, and if supply 
chain integration goes down, knowledge sharing will be reduced. In order to make the final judgment of the research hypotheses and these relations, this model is subjected to bootstrapping with 5000 resampling.

\section{Judgment about the Direct Relationships}

The bootstrapping results for all the relationships are significant, as shown in Table 7. The path coefficient value for $\mathrm{H}_{1}$, which connected supply chain integration and supply chain performance is statistically significant, with $\beta=0.259$ and $t=3.989(p<0.001)$. The second hypothesised relationship between supply chain integration and knowledge sharing was supported $\left(\mathrm{H}_{2}\right)$ with $\beta=0.449, t$-value $=$ $7.498(p<0.001)$. The third hypothesised a positive relationship between knowledge sharing and supply chain performance was also supported $\left(\mathrm{H}_{2}\right)$ with $\beta=0.289$ and $t$-value $=3.582(p<0.001)$. Hence, all the direct relationships among the constructs are significantly supported as proposed in the conceptual model at $p<0.01$ level and $t$-statistics values greater than 2.58. This indicates the model has successfully explained the direct relationships intended to be tested in this study.

Table 7

Hypothesis Testing

\begin{tabular}{lllllll}
\hline Hypothesis & Relationships & $\beta$ & $\begin{array}{l}\text { Stand } \\
\text { Dev }\end{array}$ & t-Statistics & P-Value & Support \\
& & & & & \\
\hline H1 & SC1 $\longrightarrow$ SCP & 0.259 & 0.060 & $3.989^{* * *}$ & 0.000 & Yes \\
H2 & SCI $\longrightarrow$ KS & 0.449 & 0.06 & $7.498^{* * *}$ & 0.000 & Yes \\
H3 & KS $\longrightarrow$ SCP & 0.289 & 0.059 & $3.582^{* * *}$ & 0.000 & Yes \\
\hline
\end{tabular}

Note: ${ }^{* * *}$ value is significant $1 \%$ ( $t$-statistics values $\left.>2.58\right) \mathrm{SCI}=$ Supplier Chain Integration, $\mathrm{KS}=$ Knowledge Sharing, $\mathrm{SCP}=$ Strategic Chain Performance

\section{Mediation Effect}

In order to check the influence of knowledge sharing as a mediator in the relationship between supply chain integration and supply chain 
performance relation, the variance accounted for (VAF) analysis was conducted (Hair et al. 2017). In the analysis, the indirect effect of supply chain integration to supply chain performance was measured from the model output. PLS algorithm was run on the full model to test the mediation effect. The result in Table 7 shows significant relationship between SCI and KS with $\beta=0.449, t$-value $=7.498$ $(p<0.001)$, a significant relationship between KS and SCP with $\beta=0.289$ and $t$-value $=3.582(p<0.001)$ as well, and a significant relationship between SCI and SCP with $\beta=0.259$ and $t=3.989(p<0.001)$. Hence, the path coefficient for the direct effect of supply chain integration into supply chain performance is statistically significant, and the indirect effect is statistically significant. The calculation for mediation effect is shown below:

$$
V A F=\frac{\mathrm{a} * \mathrm{~b}}{\mathrm{a} * \mathrm{~b}+\mathrm{c}}
$$

$\mathrm{VAF}=$ Variance Accounted Factor, a=Direct Effect between SCI-KS, b=Direct Effect between KS-SCP $c=$ Direct Effect between SCI-SCP

$$
V A F=\frac{0.449 * 0.289}{0.449 * 0.289+0.259}=0.3338
$$

The value of VAF is 0.3338 , which means 33.38 percent of the total effect of supply chain integration on supply chain performance is explained by the indirect effect of knowledge sharing. Moreover, according to Hair et al. (2017), if the VAF is greater than 20 percent and less than 80 percent, one can conclude a partial moderation. This means that KS partially mediates the relationship between SCI and SCP. Thus, H4 is accepted.

\section{Discussions and Implications}

The findings reveal that there is a significant positive relationship between supply chain integration and supply chain performance with $\beta=0.259, t=3.989(p<0.001)$. The findings derived from this study are in line with those of most researchers in this domain (e.g., Cagliano et al., 2006; Danese \& Romano, 2011; Droge et al., 2012; He et al., 2014; Huo, 2012; Flynn et al., 2010; Wong et al., 2011a), who believed that supply chain integration leads to an improved performance. 
The finding of this study also reveal that there is a significant positive relationship between knowledge sharing and supply chain performance with $\beta=0.289, \mathrm{t}=3.582(\mathrm{p}<0.001)$. The results indicate that the higher the knowledge sharing is, the higher the supply chain performance. Empirically, this finding is consistent with that of Zhou and Benton (2007), who highlighted the significance of knowledge sharing among supply chain partners. It is also consistent with the study by $\mathrm{Wu}$ and Cheng (2008) which revealed that an elevated level of knowledge sharing among supply chain partners serves to decrease the need for inventories while raising the level of supply chain performance. Yu, Ting and Teng (2010) examined a variety of knowledge sharing situations and revealed that the supply chain partners who share more knowledge (defined as a full knowledge sharing situation) were observed to achieve a superior supply chain performance when compared to those who were less enthusiastic about knowledge sharing. The results of this study are also in line with the views of previous studies (e.g., Ding, Guo \& Liu. 2011; Marinagi, Trivellas \& Reklitis, 2015; Moon \& Lee 2014) that knowledge sharing within an organization and among supply chain partners plays an important role during the efforts to enhance supply chain performance.

Moreover, the results acquired through this investigation support the third hypothesis (H3) which indicates a direct, significant, and positive effect of supply chain integration on knowledge sharing. The findings reveal that there is a significant positive relationship between supply chain integration and knowledge sharing, with $\beta=$ $0.449, \mathrm{t}=7.498(\mathrm{p}<0.001)$. The results indicate that the higher the supply chain integration, the higher the knowledge sharing. This finding is in agreement with the Transaction Cost Theory. Empirically, this finding is consistent with that of Croom et al. (2007), who highlighted that integration within the organisation and throughout the supply chain plays a significant role in enhancing knowledge sharing. It is also consistent with the study by D'amours et al. (1999) which uncovered the importance of supply chain integration in enhancing knowledge sharing. The results of this study are also in line with the views of previous studies (Gaonkar \& Viswanadham, 2001; Konukcu, 2011; Montoya-Torres \& Ortiz-Vargas, 2014; Olorunniwo \& Li, 2010) that the benefit of supply chain integration promotes organisational relationships which enhance knowledge and information sharing efforts. 
Finally, an indirect relationship between supply chain integration and supply chain performance through the mediation of knowledge sharing was predicted. In testing the stated hypothesis, the PLS algorithm and bootstrapping method were used. To confirm the mediation effect, the variance accounted factor (VAF) is calculated. The results supported a significant partial mediation of knowledge sharing between supply chain integration and supply chain performance. Thus, the finding of this study supports the fourth hypothesis $(\mathrm{H} 4)$, which indicates that knowledge sharing partially mediates the relationship between supply chain integration and supply chain performance. Empirically, this finding is consistent with the previous studies which explained the relationship between supply chain integration and knowledge sharing and argued that supply chain integration facilitates knowledge sharing among supply chain partners (e.g., Barratt \& Barratt, 2011; Kanda \& Deshmukh, 2008). Hence, a high level of supply chain integration leads to a high level of knowledge sharing.

Additionally, the result of this study is consistent with KnowledgeBased View which explains the importance of knowledge as a source of competitive advantage (Grant, 1996a). Knowledge-Based View also argued that knowledge sharing affects supply chain performance (Grant, 1996b; Grant, 2011; Sáenz et al., 2012). The more knowledge is shared within the organization and among supply chain partners, the more benefits the organisations are expected to gain, such as, enhancing supply chain performance. Empirically, this finding is consistent with Prahinski and Benton's (2004) who ascertained that knowledge sharing substantially improves the relationship among supply chain partners. Moreover, Barratt and Barratt (2011) put forward that knowledge sharing has come to be accepted as an effective means for managing supply chains and enhancing their performance. In addition, knowledge sharing becomes a key driver of effective and efficient supply chain performance (Kembro \& Näslund, 2014; Kembro et al., 2014; Li \& Lin, 2006).

Theoretically, this study expands the knowledge of supply chain management and knowledge management. The findings of this study disclose certain theoretical implications regarding Transaction Cost Theory and Knowledge-Based View. Firstly, the results attained through this study disclose the theoretical implications of 
the Knowledge-Based View. According to this theory, competitive advantage stems mainly from the possession of knowledge. The empirical results realised from this study demonstrate the significant role of knowledge sharing in the integration between supply chain partners, which in turn contributes to the ultimate performance of the operational and strategic supply chain. Additionally, contrary to a number of previous studies which considered knowledge sharing from one perspective, this study takes the stand of viewing knowledge sharing from the perspective of internal organisational (within an organisation) and external organisation (suppliers and customers). The empirical findings complement the previous studies that knowledge sharing generates values for supply chain integration which is essential for enhancing supply chain performance. This study substantiates the standing of knowledge as a crucial source for the establishment of a competitive advantage that enhances supply chain performance.

Secondly, integration is a decisive factor during the deliberations on "buy" or "make", and it justifies the involvement of organisation transactions. According to Transaction Cost Theory, if the cost for providing goods or services through the market is lower than having it provided internally, then integration is the key. The integration between customer and supplier enhances the capacity to provide a competitive advantage in order to enhance the performance. The empirical results derived from this study indicate the potential for operational and strategic chain performance enhancement through supply chain integration. Contrary to several previous studies that examined supply chain integration based on one or two dimensions, this effort approaches supply chain integration by capturing all dimensions (internal integration, customer integration and supplier integration). This contributes towards the preliminary knowledge required for the development of supply chain theory.

Practically, the results realised through this study have several implications for managers. Firstly, managers need to be well-informed of the importance of knowledge sharing in an organisation and with supply chain partners. This requirement is related to the fact that knowledgesharingisa prominentfacilitator of supply chainintegration. This study suggests that managers need to encourage knowledge sharing behaviours among employees, between departments, with 
their supply chain partners and with their customers. For instance, continuous knowledge sharing between supplier and customer may provide a basis for both of them to collaborate and to act towards each other appropriately for increasing performance. Such a move will undoubtedly improve the performance of the supply chain.

In addition, managers need to consider internal integration as a wellsynchronised working situation that can facilitate the achievement of organisational objectives. For instance, managers ought to conduct structural meetings involving departmental managers to discuss all essential correlated functions and procedures. These meetings should include the use of product roadmaps and performance metrics. This will go a long way towards enhancing awareness on responsibility and avoiding overlapping roles. It will also benefit managers in decision-making positions and develop a sense of harmony among departments. The significance of internal integration and external integration with customers and suppliers during efforts to gain competitive advantage cannot be downplayed. Thus, keeping a watchful eye on the level of external integration should be part and parcel of a manager's role. As for customer integration, managers ought to build up customer relationship by thinking beyond sealing transactions, addressing customer needs and synchronising the main activities with key customers. Also, it is notable that a high degree of supplier integration improves performances. As such, managers are called to fortify the relationship with suppliers by addressing individual supplier capabilities, synchronising the main activities with key suppliers and delving into the search for new opportunities for both parties. Managers who comprehend the impact of integration on performance can outperform their competitors and initiate improvements to the general performance of the supply chain.

Although this study was conducted in Jordan, companies from South East Asia could learn from these findings on how to manage and integrate their supply chain with their partners in an effective and efficientmanner. Thefindingsemphasise theimportance of information and knowledge sharing among the supply chain partners to allow all partners such as suppliers and customers to collaborate and benefit from this integration, hence, increasing their performances. It could be postulated that this success is because the partners understand the importance of knowledge sharing and put them into practice. 
Furthermore, it could also be due to the knowledge sharing that is instilled by their culture and religion. Hence, the South East Asia companies should create awareness on the importance of knowledge among the suppliers and customers so that this knowledge sharing culture could be inculcated in them.

\section{Conclusion}

This study has filled the gaps in understanding the role of knowledge sharing as a mediator in the relationship between supply chain integration and supply chain performance. The study used a survey method in collecting data from 277 managers from various sectors in the manufacturing industry in Jordan. The results from PLS Structural Equation Modeling show a significant positive relationship between supply chain integration and supply chain performance and knowledge sharing plays partial mediation in this relationship. This study provides an important implication on the significant role of knowledge sharing in the integration between supply chain partners which, in turn, contributes to the ultimate performance of the operational and strategic supply chain. The performance of the supply chain can be maximised if the supply chain partners share knowledge among them. This will expedite the process of delivering the products to the customers. Practically, management could raise awareness among partners on the importance to share and utilise knowledge better for the benefits of both parties.

While this study has unearthed several significant theoretical and practical implications, it is also hindered by certain limitations. The current study only concentrates on the supply chain integration and knowledge sharing as a strategy to control the flow of the supply chain resources to improve the supply chain performance through the data gathered from single respondents of the manufacturing organization. Even though a supply chain integration and knowledge sharing need a dyad or triadic relationships, future research should consider a multiple informant approach in order to better understand the benefits of dyadic level or triadic level of supply chain integration and knowledge sharing. An examination of the current study model on dyadic or triadic levels might expose a more complex dynamic relationship among supply chain partners. 


\section{Acknowledgements}

This work was supported by the Dana UKM GSB-022-2010.

\section{References}

Alavi, M., \& Leidner, D. E. (2001). Review: Knowledge management and knowledge management systems: Conceptual foundations and research issues. Management Information Systems Quarterly, 25(1), 107-136.

Barratt, M., \& Barratt, R. (2011). Exploring internal and external supply chain linkages: Evidence from the field. Journal of Operations Management, 29(5), 514-528.

Boon-Itt, S. (2011). Achieving product quality performance: The roles of supply chain integration and information technology. International Journal of Innovation Management and Technology, 2(5), 373-376.

Braunscheidel, M. J., \& Suresh, N. C. (2009). The organizational antecedents of a firm's supply chain agility for risk mitigation and response. Journal of Operations Management 27(2),119-140.

Cagliano, R. , Caniato, F., \& Spina, G. (2006). The linkage between supply chain integration and manufacturing improvement programmes. International Journal of Operations \& Production Management, 26(3), 282-299.

Cheng, J.-H., \& Fu, Y.-C. (2013). Inter-organizational relationships and knowledge sharing through the relationship and institutional orientations in supply chains. International Journal of Information Management, 33(3), 473-484.

Cheng, J. H. (2011). Inter-organizational relationships and information sharing in supply chains. International Journal of Information Management, 31(4), 374-384.

Chin, W. W., Marcolin, B. L., \& Newsted, P. R. (2003). A partial least squares latent variable modeling approach for measuring interaction effects: Results from a Monte Carlo simulation study and an electronic-mail emotion/adoption study. Information Systems Research, 14(2), 189-217.

Choi, B., \& Lee, H. (2003). Knowledge management enablers, processes, and organizational performance: An integration and empirical examination. Journal of Management Information Systems, 20(1), 179-228. 
Cohen, J. (1988). Statistical power analysis for the behavioral sciences (2nd ed.). Hillsdale, New Jersey: Erlbaum.

Cousins, P. D., \& Menguc, B. (2006). The implications of socialization and integration in supply chain management. Journal of Operations Management, 24(5), 604-620.

Craighead, C. W., Ketchen, D., Dunn, K. S., \& Hult, G. (2011). Addressing common method variance: Guidelines for survey research on information technology, operations, supply chain management. IEEE Transactions on Engineering Management, 58(3), 578-588.

Croom, S. , Fawcett, S. E. , Osterhaus, P., Magnan, G. M., Brau, J. C., \& Mccarter, M. W. (2007). Information sharing and supply chain performance: The role of connectivity and willingness. Supply Chain Management: An International Journal, 12(5), 358-368.

D'amours, S., Montreuil, B., Lefrancois, P., \& Soumis, F. (1999). Networked manufacturing: The impact of information sharing. International Journal of Production Economics, 58(1), 63-79.

Danese, P., \& Romano, P. (2011). Supply chain integration and efficiency performance: A study on the interactions between customer and supplier integration. Supply Chain Management: An International Journal, 16(4), 220-230.

Ding, H., Guo, B., \& Liu, Z. (2011). Information sharing and profit allotment based on supply chain cooperation. International Journal of Production Economics, 133(1), 70-79.

Droge, C. , Vickery, S. K., \& Jacobs, M. A. (2012). Does supply chain integration mediate the relationships between product/ process strategy and service performance? An empirical study. International Journal of Production Economics, 137(2), 250-262.

Dyer, J., \& Nobeoka, K. (2002). Creating and Managing a high performance knowledge-sharing network: The Toyota case. Strategic Management Journal, 21(3), 345-367.

Flynn, B. B., Huo, B., \& Zhao, X. (2010). The impact of supply chain integration on performance: A contingency and configuration approach. Journal of Operations Management, 28(1),58-71.

Frohlich, M. T., \& Westbrook, R. (2001). Arcs of integration: An international study of supply chain strategies. Journal of Operations Management, 19(2), 185-200.

Fynes, B., Voss, C., \& De Búrca, S. (2005). The impact of supply chain relationship quality on quality performance. International Journal of Production Economics, 96(3), 339-354. 
Gaonkar, R., \& Viswanadham, N. (2001). Collaboration and information sharing in global contract manufacturing networks. IEEE/ASME Transactions on Mechatronics, 6(4), 366-376.

Goury, M. L., Samuel, K. E., Gunasekaran, A., \& Spalanzani, A. (2011). Knowledge management in supply chain: An empirical study from France. The Journal of Strategic Information Systems, 20(3), 283-306.

Govindarajan, V., \& Gupta, A. K. (2001). Strategic innovation: A conceptual road map. Business Horizons, 44(4), 3-12.

Grant, K. (2011). Knowledge management, an enduring but confusing fashion. The Electronic Journal of Knowledge Management, 9(2), 1117-1131.

Grant, R. M. (1996a). Prospering in dynamically-competitive environments: Organizational capability as knowledge integration. Organization Science, 7(4), 375-387.

Grant, R. M. (1996b). Toward a knowledge-based theory of the firm. Strategic Management Journal, 17(S2), 109-122.

Gunasekaran, A., Papadopoulos, T., Dubey, R., Wamba, S. F., Childe, S. J., Hazen, B., \& Akter, S. (2017). Big data and predictive analytics for supply chain and organizational performance. Journal of Business Resarch, 70, 308-317.

Hair, J. F., Hult, G. T. M., Ringle, C. M., \& Sarstedt, M. (2017). A primer on partial least squares structural equation modeling (Plssem) (2nd ed.). Thousand Oaks, CA: Sage.

Hair, J. F. M., Sarstedt, Lucas, H., \& Volker, G. K. (2014a). Partial least squares structural equation modeling (Pls-sem). European Business Review, 26(2), 106-121.

He, Y., Keung Lai, K., Sun, H., \& Chen, Y. (2014). The impact of supplier integration on customer integration and new product performance: The mediating role of manufacturing flexibility under trust theory. International Journal of Production Economics, 147(PB), 260-270.

Henseler, J., \& Chin, W. W. (2010). A comparison of approaches for the analysis of interaction effects between latent variables using partial least squares path modeling. Structural Equation Modeling, 17(1), 82-109.

Huang, C. C., \& Lin, S. H. (2010). Sharing knowledge in a supply chain using the semantic web. Expert Systems with Applications, 37(4), 3145-3161.

Huang, M.-C. , Yen, G.-F. \& Liu, T.-C. (2014). Reexamining supply chain integration and the supplier's performance relationships 
under uncertainty. Supply Chain Management: An International Journal, 19(1), 64-78.

Hugos, M. H. (2018). Essentials of supply chain management. Hoboken, New Jersey: John Wiley \& Sons.

Huo, B. (2012). The impact of supply chain integration on company performance: An organizational capability perspective. Supply Chain Management: An International Journal, 17(6), 596-610.

Ingram, P., \& Baum, J. A. C. (1997). Opportunity and constraint: Organizations' learning from the operating and competitive experience of industries. Strategic Management Journal, 18(S1), 75-98.

Kaipia, R. (2009). Coordinating material and information flows with supply chain planning. The International Journal of Logistics Management, 20(1), 144-162.

Kanda, A., \& Deshmukh, S. (2008). Supply chain coordination: perspectives, empirical studies and research directions. International Journal of Production Economics, 115(2), 316-335.

Kembro, J., \& Näslund, D. (2014). Information sharing in supply chains, myth or reality? A critical analysis of empirical literature. International Journal of Physical Distribution $\mathcal{E}$ Logistics Management, 44(3), 179-200.

Kembro, J., Selviaridis, K., \& Näslund, D. (2014). Theoretical perspectives on information sharing in supply chains: A systematic literature review and conceptual framework. Supply Chain Management: An International Journal, 19(5/6), 609-625.

Khalfan, M. M., Kashyap, M., Li, X., \& Abbott, C. (2010). Knowledge management in construction supply chain integration. International Journal of Networking and Virtual Organisations, 7(2), 207-221.

Konukcu, S. (2011). A knowledge chain framework for construction supply chains. Place: Loughborough University.

Lee, H. L., So, K. C., \& Tang, C. S. (2000). The value of information sharing in a two-level supply chain. Management Science, 46(5), 626-643.

Leiponen, A. (2006). Managing knowledge for innovation: The case of business-to-business services. Journal of Product Innovation Management, 23(3), 238-258.

Li, J., Sikora, R., Shaw, M. J., \& Tan, G. W. (2006). A strategic analysis of inter organizational information sharing. Decision Support Systems, 42(1), 251-266. 
Li, S., \& Lin, B. (2006). Accessing information sharing and information quality in supply chain management. Decision Support Systems, 42(3), 1641-1656.

$\mathrm{Li}, \mathrm{X} ., \& \mathrm{Hu}$, J. (2012). Business impact analysis based on supply chain's knowledge sharing ability. Procedia Environmental Sciences, 12, 1302-1307.

Lotfi, Z., Mukhtar, M., Sahran, S., \& Zadeh, A. T. (2013). Information sharing in supply chain management. Procedia Technology, 11, 298-304.

Lowry, P. B., \& Gaskin, J. (2014). Partial least squares (PLS) Structural equation modeling (sem) for building and testing behavioral causal theory: When to choose it and how to use it. IEEE Transactions on Professional Communication, 57(2), 123-146.

Lyons, A., Coleman, J., Kehoe, D., \& Coronado, A. (2004). Performance observation and analysis of an information re-engineered supply chain: A case study of an automotive firm. Industrial Management \& Data Systems, 104(8), 658-666.

Marinagi, C., Trivellas, P., \& Reklitis, P. (2015). Information quality and supply chain performance: The mediating role of information sharing. Procedia-Social and Behavioral Sciences, 175, 473-479.

Marra, M., Ho, W., \& Edwards, J. S. (2012). Supply chain knowledge management: A literature review. Expert Systems with Applications, 39(5), 6103-6110.

Martín-De Castro, G., Andreeva, T., \& Kianto, A. (2011). Knowledge processes, knowledge-intensity and innovation: A moderated mediation analysis. Journal of Knowledge Management, 15(6), 1016-1034.

Montoya-Torres, J. R., \& Ortiz-Vargas, D. A. (2014). Collaboration and information sharing in dyadic supply chains: A literature review over the period 2000-2012. Estudios Gerenciales, 30(133), 343-354.

Moon, H., \& Lee, C. (2014). The mediating effect of knowledge-sharing processes on organizational cultural factors and knowledge management effectiveness. Performance Improvement Quarterly, 26(4), 25-52.

Näslund, D. \& Hulthen, H. (2012). Supply chain management integration: A critical analysis. Benchmarking: An International Journal, 19(4/5), 481-501.

Niu, Y. (2010). The impact of information technology on supply chain performance: A knowledge management perspective (Unpublished 
doctoral dessertation). The University of North Carolina at Charlotte.

Nonaka, I., \& Takeuchi, H. (1995). The knowledge-creating company: How Japanese companies create the dynamics of innovation. Oxford: Oxford University Press.

Olorunniwo, F. O., \& Li, X. (2010). Information sharing and collaboration practices in reverse logistics. Supply Chain Management: An International Journal, 15(6), 454-462.

Petersen, K. J., Handfield, R. B., \& Ragatz, G. L. (2005). Supplier integration into new product development: Coordinating product, process and supply chain design. Journal of Operations Management, 23(3), 371-388.

Podsakoff, P. M., Mackenzie, S. B., Lee, J.-Y., \& Podsakoff, N. P. (2003). Supplier evaluations: Communication strategies to improve supplier performance. Journal of Operations Management, 22(1), 39-62.

Prahinski, C., \& Benton, W. (2004). Supplier evaluations: Communication strategies to improve supplier performance. Journal of Operations Management, 22(1), 39-62.

Reychav, I. (2009). Knowledge sharing in a trade show: A learning spiral model. Vine, 39(2), 143-158.

Ringle, C. M., Wende, S., \& Becker, J.-M. (2015). Smartpls3 boenningstedt: SmartPLS GmbH. Retrieved from http://www. smartpls. com

Saraf, N., Langdon, C. S., \& Gosain, S. (2007). Is application capabilities and relational value in interfirm partnerships. Information Systems Research, 18(3), 320-339.

Sáenz, J., Aramburu, N., \& Blanco, C. E. (2012). Revisiting the arcs of integration: Cross-validations and extensions. Journal of Operations Management, 30(1), 99-115.

Schoenherr, T., \& Swink, M. (2012). Revisiting the arcs of integration: Cross-validations and extensions. Journal of Operations Management, 30(1), 99-115.

Stock, J. R., Boyer, S. L., \& Harmon, T. (2010). Research opportunities in supply chain management. Journal of the Academy of Marketing Science, 38(1), 32-41.

Vallet-Bellmunt, T., \& Rivera-Torres, P. (2013). Integration: Attitudes, patterns and practices. Supply Chain Management: An International Journal, 18(3), 308-323.

Wang, C., \& Hu, Q. (2017). Knowledge sharing in supply chain networks: Effect of collaorative activities and capability on 
innovation performance. Technocation. Available on line 16 December 2017??. URL link

Willamson, O. (1985). The economic institutions of capitalism: firms, markets, relational contracting. Place: Publisher

Williams, B. D., Roh, J., Tokar, T., \& Swink, M. (2013). Leveraging supply chain visibility for responsiveness: The moderating role of internal integration. Journal of Operations Management, 31(7), 543-554.

Winter, S. G. (1988). On coase, competence, and the corporation. Journal of Law, Economics and Organization, 4(1), 163-180.

Wong, C. Y., Boon-Itt, S., \& Wong, C. W. Y. (2011a). The contingency effects of environmental uncertainty on the relationship between supply chain integration and operational performance. Journal of Operations Management, 29(6), 604-615.

Wong, C. W., Lai, K. H., \& Cheng, T. C. (2011b). Value of information integration to supply chain management: roles of internal and external contingencies. Journal of Management Information Systems, 28(3), 161-200.

Wong, K. K. K. (2013). Partial least squares structural equation modeling (pls-sem) techniques using smartpls. Marketing Bulletin, 24(1), 1-32.

Wu, L., \& Zang, Y. (2009). A multi-agent and case-based reasoning framework for knowledge sharing in supply chain. IEEE International Conference on Intelligent Computing and Intelligent Systems, 575-579.

Wu, Y. N., \& Edwin Cheng, T. C. (2008). The impact of information sharing in a multiple-echelon supply chain. International Journal of Production Economics, 115(1), 1-11.

Yifei, Z., \& Taofei, K. (2010). Analysis and evaluation on the efficiency of knowledge sharing in supply chain. The 2nd IEEE International Conference on Information Management and Engineering (ICIME), 11-14.

Yu, M.M. , Ting, S. C., \& Chen, M. C. (2010). Evaluating the crossefficiency of information sharing in supply chains. Expert Systems with Applications, 37(4), 2891-2897.

Yurong, Z., \& Mingwei, L. (2010). Study on the influencing factors of knowledge sharing in supply chain. International Conference on Intelligent Computation Technology and Automation (ICICTA), 602-605.

Zhang, C., Gunasekaran, A., \&Wang, W. Y.C. (2015). A comprehensive model for supply chain integration. Benchmarking: An International Journal, 22(6), 1141-1157. 
IJMS 26(2), 21-51 (2019)

Zhao, X. , Huo, B., Selen, W., \& Yeung, J. H. Y. (2011). The impact of internal integration and relationship commitment on external integration. Journal of Operations Management, 29(1), 17-32.

Zhou, H., \& Benton, W. (2007). Supply chain practice and information sharing. Journal of Operations Management, 25(6), 1348-1365. 